\title{
The Prologue of the Gospel of John
}

Its Literary, Theological, and Philosophical Contexts. Papers read at the Colloquium Ioanneum 2013

Ed. by Jan G. van der Watt, R. Alan Culpepper, and Udo Schnelle

[Der Prolog des Johannesevangeliums. Seine literarischen, theologischen und philosophischen Kontexte. Beiträge vom Colloquium Ioanneum 2013.]

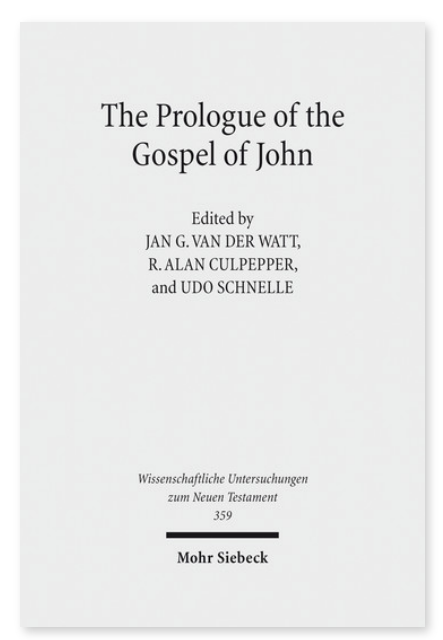

2016. XXII, 342 Seiten. WUNT I 359

ISBN 978-3-16-154772-0

DOI 10.1628/978-3-16-154772-0

eBook PDF 154,00 €

ISBN 978-3-16-154771-3

Leinen $154,00 €$
Veröffentlicht auf Englisch.

Der Prolog ist in vielerlei Hinsicht der Schlüssel für das Verstehen des gesamten Johannesevangeliums. Zugleich bleiben viele Fragen seines Ursprungs und Hintergrundes, seiner Struktur und der Herkunft der ihn prägenden Begriffe offen. Die Beiträge des vorliegenden Bandes erörtern diese Fragen und führen sie einer möglichen Beantwortung zu. Es sind die Vorträge der ersten Konferenz des Colloquium loanneum, einer internationalen Vereinigung von Exegeten und Exegetinnen, die in besonderer Weise zum Johannesevangelium gearbeitet haben. Der erste Teil des Bandes widmet sich dem religionsgeschichtlichen, literarischen und theologischen Hintergrund des Prologs, im zweiten Teil werden Perspektiven und Methoden einer philosophischen Interpretation des Prologs und des gesamten Johannesevangeliums präsentiert.

Inhaltsübersicht

Part 1: Confronting the Challenges of the Prologue

R. Alan Culpepper: The Prologue as Theological Prolegomenon to the Gospel of John - John Ashton: Really a Prologue? William R. G. Loader: The Significance of the Prologue for Understanding John's Soteriology - Jan G. van der Watt: John 1:1 - A »Riddle«? Grammar and Syntax Considered - Catrin H. Williams: (Not) Seeing God in the Prologue and Body of John's Gospel Ruben Zimmermann: John (the Baptist) as a Character in the Fourth Gospel: The Narrative Strategy of a Witness Disappearing - Michael Theobald: Eine Gemeinschaft von »Zeugen« (von Joh 1:7, 15 bis 3 Joh 12): Beobachtungen zur Genese des Corpus Iohanneum auf der Basis des Prologs - Christos Karakolis: The Logos-Concept and Dramatic Irony in the Johannine Prologue and Narrative

Part 2: Reading the Language and Concepts of the Prologue in Their Philosophical Context

Udo Schnelle: Philosophische Interpretation des Johannesevangeliums: Voraussetzungen, Methoden und Perspektiven - Jörg Frey: Between Torah and Stoa: How Could Readers Have Understood the Johannine Logos? - Craig R. Koester: »Spirit« (Pneuma) in Greco-Roman Philosophy and the Gospel of John - George L. Parsenios: Confounding Foes and Counseling Friends: Parrēsia in the Fourth Gospel and Greco-Roman Philosophy - Marianne Meye Thompson: »Light« ( $\varphi \tilde{\omega} \varsigma)$ : The

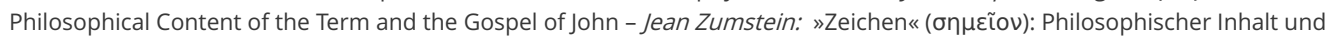
Gebrauch des Begriffs im Johannesevangelium

Jan G. van der Watt Born 1952; emeritus professor of the University of Pretoria (South Africa) and Radboud University Nijmegen (Netherlands) as well as research associate University of the Free State (South Africa).

R. Alan Culpepper Born 1946; PhD from Duke University; taught at the Southern Baptist Theological Seminary, Baylor University, and Mercer University, founding dean of the McAfee School of Theology at Mercer University; retired since 2016.

Udo Schnelle Geboren 1952; Studium, Promotion und Habilitation in Göttingen; Pastor der Hannoverschen Landeskirche; 1986-92 Professor für Neues Testament in Erlangen, 1992-2017 in Halle; seit 2017 im Ruhestand.

Jetzt bestellen:

https://mohrsiebeck.com/buch/the-prologue-of-the-gospel-of-john-9783161547720?no_cache=1 order@mohrsiebeck.com

Telefon: +49 (0)7071-923-17

Telefax: +49(0)7071-51104 